\title{
What can be learned from the K-Ar ages of illite from Rotliegend sandstones of the Fore-Sudetic Monocline, SW Poland?
}

\author{
Julita BIERNACKA ${ }^{1, *}$ \\ 1 University of Poznań, Institute of Geology, Maków Polnych 16, 61-606 Poznań, Poland
}

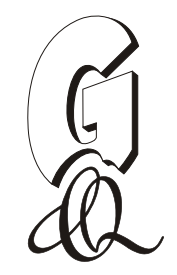

\begin{abstract}
Biernacka, J., 2015. What can be learned from the K-Ar ages of illite from Rotliegend sandstones of the Fore-Sudetic Monocline, SW Poland? Geological Quarterly, 59 (2): 257-270, doi: 10.7306/gq.1210

The available K-Ar ages of authigenic illite from Rotliegend aeolian sandstones of the Fore-Sudetic Monocline, SW Poland, including those from six samples examined in the present study, are critically reviewed in terms of their geological meaning and compared with the K-Ar ages of illite from the remaining part of the Southern Permian Basin in Europe. The majority of ages fall in the range between 195 and $150 \mathrm{Ma}$, i.e. they correspond to Jurassic times. The results may be grouped in several time intervals, which are almost identical to those identified for Rotliegend sandstones of Central and Western Europe, and which are tentatively interpreted as pulses of intense illite growth. Short-lasting illitisation is recorded only at places. More often, illitisation proceeded as a multi-stage process, which in the northern part of the Fore-Sudetic Monocline might have lasted until the Cretaceous. The K-Ar ages of authigenic illite generally coincide with the modelled time of gas generation from Carboniferous rocks and the filling of reservoirs in the area of the Fore-Sudetic Monocline. Possibly, the same underlying processes triggered illitisation and hydrocarbon expulsion, or hydrocarbon migrations triggered fluid flows and illite crystallisation.
\end{abstract}

Key words: K-Ar dating, illite, sandstone, Rotliegend, Southern Permian Basin, Poland.

\section{INTRODUCTION}

Diagenetic processes occurring in sedimentary rocks reflect to varying degrees the evolution of sedimentary basins. When this evolution has been long and complex, the overall pattern of diagenetic alteration may be also complex and not straightforward to decipher. In this respect, the timing of main diagenetic stages is of key importance. The timing of diagenesis in siliciclastic reservoirs is of special interest because this knowledge facililates petroleum system modelling and helps to assess prospective rocks/areas. The potassium-argon (K-Ar) dating of authigenic illite is one of a few methods yielding numerical data; it has been used for years and still shows wide applicability (Clauer, 2013). However, the results may be biased by contamination of irremovable detrital illite and other K-bearing phases, as well as by procedural errors (Hamilton et al., 1989; Clauer, 2013). Besides, the interpretation of the results obtained from pure authigenic illite is also a challenge because the dates rarely correspond directly to meaningful geological events (e.g., Hamilton et al., 1989; Pevear, 1999; Środoń et al., 2002; Meunier et al., 2004). Rather, they can be averages for mixtures of illites of different ages.

*E-mail: julbier@amu.edu.pl

Received: August 26, 2014; accepted: November 14, 2014; first published online: December 29, 2014
Rotliegend sandstones of Central and Western Europe form numerous deeply buried gas-reservoirs. Their diagenetic histories were studied in numerous cases and constrained by illite K-Ar isotope data (Lee et al., 1989; Platt, 1993; Robinson et al., 1993; Ziegler et al., 1994; Zwingmann et al., 1998, 1999; Liewig and Clauer, 2000; Clauer et al., 2012). These datings are believed to be important for several reasons. (1) They deliver a quantitative time-framework for the precipitation of a major authigenic phase in Rotliegend sandstones. (2) It is often assumed that after gas emplacement into reservoirs, illite does not grow any further, or at least does not grow abundantly (Lee et al., 1985; Hamilton et al., 1989; Gaupp et al., 1993). Therefore, it is assumed that the K-Ar ages of the finest fraction of fibrous illite from reservoirs represent the time of cessation of illite growth, i.e. the time of hydrocarbon charge (Lee et al., 1985; Hamilton et al., 1989). Haszeldine et al. (2003) proposed the $\mathrm{K}-\mathrm{Ar}$ dating of fibrous illite as the dating of oil entrapment in reservoirs of the North Sea. (3) Illite often shows fibrous morphology, which significantly deteriorates permeability, thus K-Ar illite ages constrain good reservoir properties.

The aim of this contribution is to review all available illite $\mathrm{K}$-Ar ages obtained from aeolian Rotliegend sandstones of the Fore-Sudetic Monocline, the area situated in the eastern part of the Southern Permian Basin in Europe, and to consider two problems: Are these ages meaningful? What can be learned from the K-Ar ages of illite from Rotliegend sandstones of the Fore-Sudetic Monocline? The main source of data are the results obtained in the present study and by Maliszewska and Kuberska (2009), Protas et al. (2006), and Michalik (2001). The results are compared with the results of the K-Ar datings of 


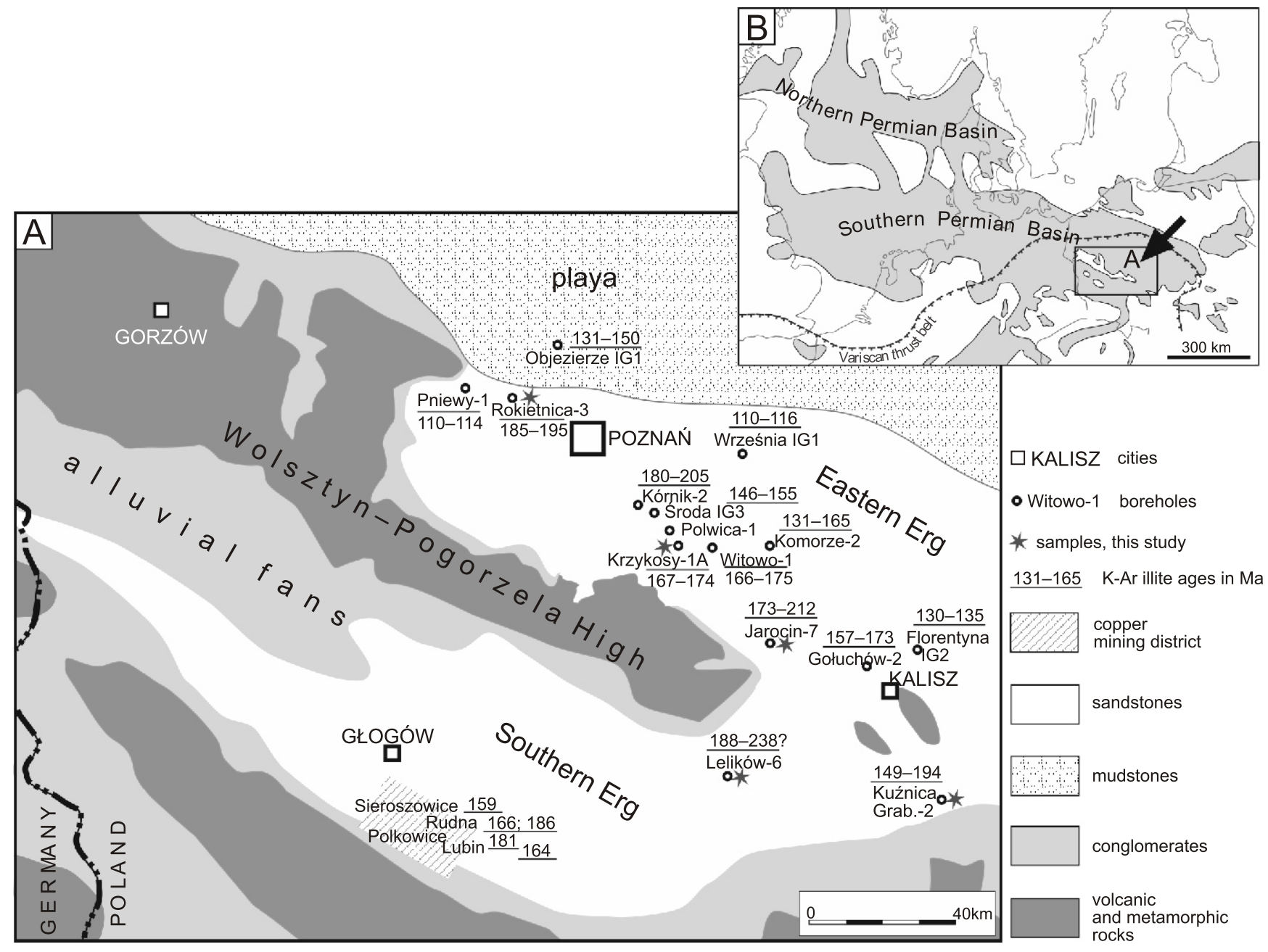

Fig. 1A - localization of boreholes mentioned in the text against the background of palaeogeography at the end of Rotliegend deposition in SW Poland (according to Gast et al., 2010; Kiersnowski et al., 2010b)

B - the extent of Rotliegend deposits in Europe after Glennie (1990) and Karnkowski (1999)

authigenic illite in Rotliegend sandstones of the remaining part of the Southern Permian Basin.

\section{GEOLOGICAL SETTING}

The study area is situated in the eastern part of the Southern Permian Basin (Fig. 1A). Permian rocks occur here in the subsurface of the Fore-Sudetic Monocline, a tectonic unit formed at the end of the Cretaceous in response to early Alpine movements. Therefore, the top of the Rotliegend is inclined towards the north-east and presently lies at various depths from $\sim 1$ to $>4 \mathrm{~km}$. The sedimentary rocks of the gas-bearing Upper Rotliegend were deposited in three depositional environments: aeolian, fluvial, and lacustrine (playa) (Figs. 1 and 2; Kiersnowski, 1997; Karnkowski, 1999). Numerous small gas traps are located in aeolian and fluvial sandstones. The upper part of aeolian sandstones shows the best reservoir properties. Carboniferous Variscan flysch deposits which occur in the basement of Permian rocks are considered as gas source rocks (Pletsch et al., 2010; Botor et al., 2013).

At the end of the Middle Permian, the Wolsztyn-Pogorzela High, a regional NW-SE striking ridge, separated two large dune fields: the Eastern Erg and the Southern Erg (Fig. 1;
Kiersnowski, 1997, 2013; Kiersnowski et al., 2010a). The aeolian sandstones of the Eastern Erg are up to 1000 m thick, whereas the aeolian sandstones of the Southern Erg reach $250 \mathrm{~m}$ in thickness (Fig. 2). The aeolian sedimentation rapidly ended with the flooding of the area by the Zechstein sea and the deposition of the Kupferschiefer - thin, organic matter-rich shale.

The post-depositional history of the Rotliegend in the Fore-Sudetic Monocline is complicated and comprises several distinct stages. High tectonic subsidence associated with high heat flow is assumed for Late Permian-Early Triassic times, followed by slower subsidence in the Middle Triassic-Late Jurassic (Karnkowski, 1999). As a result, at the end of the Jurassic the top of the Rotliegend sandstones was buried to the depths from approx. 2-3 km in the south to approx. $4-5 \mathrm{~km}$ in the north. In the Early Cretaceous, the area situated south of the Kalisz-Poznan-Szczecin line was uplifted, and erosion of part of Jurassic and Triassic sediments occurred, while the area situated north of that line still underwent small subsidence (Karnkowski, 1999). Renewed sedimentation in the entire area started in the Late Cretaceous and led to the deposition of less than $1 \mathrm{~km}($ ?)-thick sediments; a greater thickness of sediments was deposited only at the northern edge of the Fore-Sudetic Monocline (e.g., Botor, 2011). At the end of the Cretaceous and 

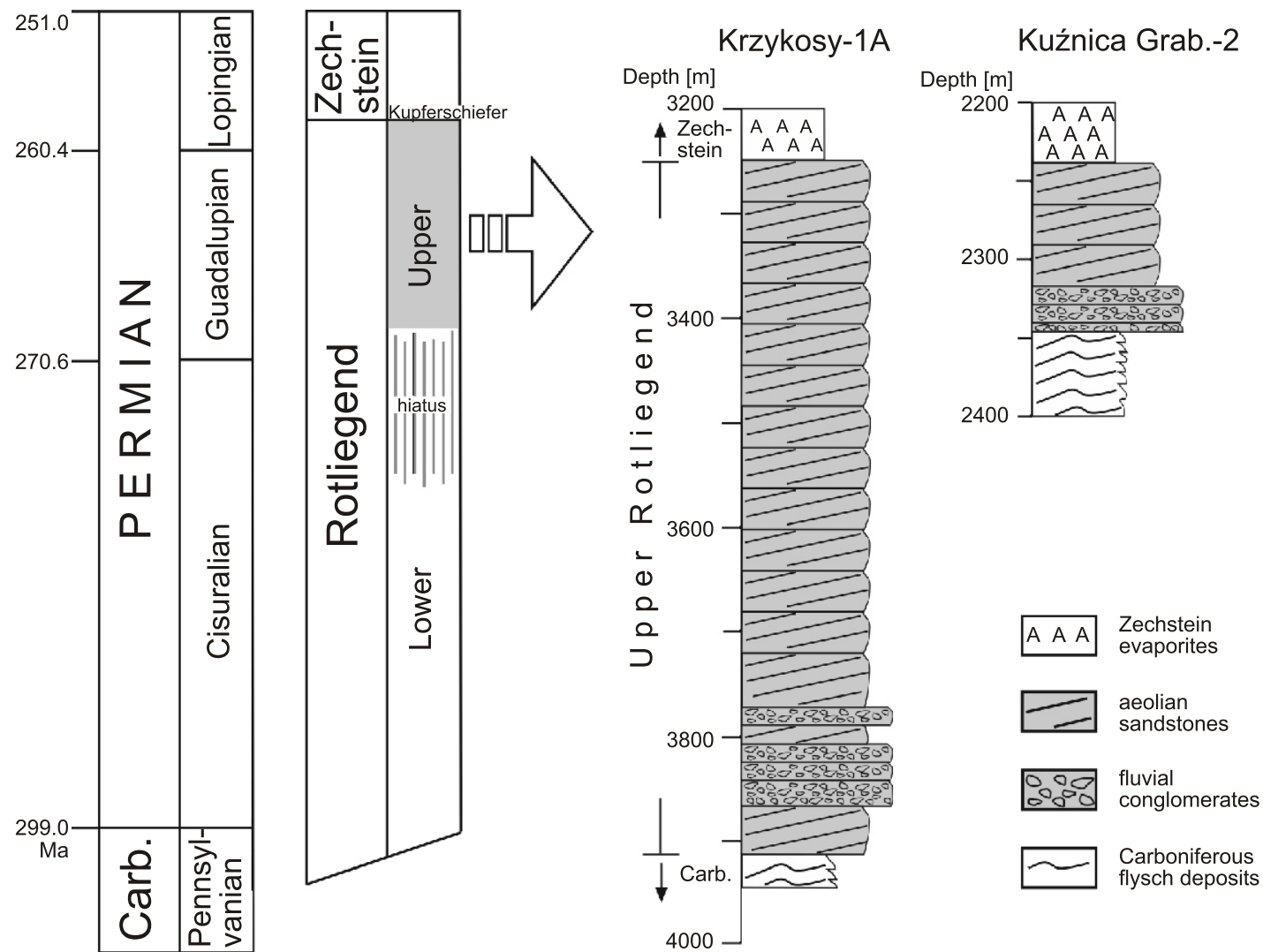

Fig. 2. Chronostratigraphy and regional subdivision of Permian, and examples of Rotliegend sections from the Fore-Sudetic Monocline (Krzykosy-1A representing the area of the Eastern Erg and Kuźnica Grab.-2 representing the area of the Southern Erg)

Numerical time-scale according to Gradstein et al. (2004); sedimentological interpretation of sections by Buniak (in Biernacka et al., 2006)

in the Paleogene, successive tectonic uplift occurred and most of the Upper Cretaceous sediments was removed. The top of the Rotliegend sandstones was then situated near the present depths of 1 to $>4 \mathrm{~km}$.

The depositional and post-depositional history of the Rotliegend in the Fore-Sudetic Monocline was tectonically controlled; several regional fault zones and numerous faults have been recognized in the subsurface (Karnkowski, 1999; Kiersnowski et al., 2010a).

\section{METHODS}

Six samples of Rotliegend aeolian sandstones rich in diagenetic illite and coming from five boreholes were selected for K-Ar datings (Fig. 1). These samples were selected from a larger set of 71 sandstone samples which had been previously studied (Biernacka et al., 2006) and whose clay minerals had been examined by XRD (Biernacka, 2014). The abundance of illite and the diversity of locations were the basis for the selection. Three samples were taken from the area of the Eastern Erg, and further three from the Southern Erg. Only Jarocin-7 2792.3 sample came from reservoir sandstones located nearby a gas deposit (Jarocin). The remaining sandstones came from water-saturated sandstones. Samples Krzykosy-1A 3878.5 and Rokietnica-3 3665.8 were taken from the lower part of aeolian successions, the remaining from the upper part.
The samples were moderately to weakly cemented, so after cleaning they were gently crushed (some with fingers) into $\sim 1-2 \mathrm{~cm}$ fragments, and then disaggregated in distilled water with an ultrasonificator. The $<2 \mu \mathrm{m}$ and $<0.2 \mu \mathrm{m}$ fractions were separated by centrifugation, Mg-saturated, and purified of excess salts by dialysis. The fractions were subsequently analysed with the use of an ARL Thermo X'tra diffractometer operated at $40 \mathrm{kV}$ and $40 \mathrm{~mA}$, with a $2 \mathrm{~mm}$ divergence slit, a $4 \mathrm{~mm}$ antiscatter slit, and receiving slits of 0.5 and $0.2 \mathrm{~mm}$. The oriented clay aggregates were analysed from 2 to $36^{\circ} 2 \theta$ as air-dried mounts and after vapour salvation in ethylene glycol (EG) at $65^{\circ} \mathrm{C}$ overnight. In addition, diffraction patterns were obtained from randomly oriented, side-loaded powders. As an estimate of illite "crystallinity", the full width at half maximum (FWHM) of the 001 reflections was measured for the air-dried $<2 \mu \mathrm{m}$ fractions. Background removing and peak fitting were performed by means of the WinXRD program of ThermoElectron. The Środon intensity ratio Ir was calculated for illite according to the formula: $I r=\left(001 / 003_{\text {air-dry }}\right) /\left(001 / 003_{\mathrm{EG}}\right)$ (Środoń, 1984).

The morphology of clay aggregates was recorded by means of a Hitachi 3700N scanning electron microscope at the Faculty of Geographical and Geological Sciences, Poznań University. Fresh-fractured sandstone pieces were coated with gold and observed in a secondary electron mode. Graphite-coated polished thin sections were also observed in a back-scattered electron mode. In addition, transmission electron micrographs of clay mineral separates were recorded at the Laboratory of 
Electron and Confocal Microscopy at Poznań University. Small volume of dispersed clay minerals was dropped on a microcarbon film on a copper grid and observed in a Jeol JEM 1200Ex transmission electron microscope.

The K-Ar isotopic determinations were performed in the Clay Minerals Laboratory of the Polish Academy of Sciences in Cracow (ING PAN Kraków) by M. Banaś, following the procedures described in Środoń et al. (2006). The $<2 \mu \mathrm{m}$ fractions separated as above underwent further separation into 2.0-0.5, $0.5-0.2$, and $<0.2 \mu \mathrm{m}$ subfractions in a Beckman high-speed centrifuge. Then, each sample was split into two aliquots for argon and potassium determinations. The Ar isotopic compositions were determined by a MS-20 mass spectrometer with an internal spike. The samples were wrapped in an Al-foil and preheated overnight at $100^{\circ} \mathrm{C}$ under vacuum to remove atmospheric Ar. The gases were then extracted from the samples in a doubly-vacuum Mo-Ti crucible mounted in a resistant furnace at $\sim 1200^{\circ} \mathrm{C}$ for $60 \mathrm{~min}$. The noble gases were further purified from active gases in a $U$-trap cooled with liquid nitrogen, in a $\mathrm{Ti}$ oven, and the final purification was conducted by a hot-getter pump (SAES Getter SJ-5) and lasted between 4 and 48 hours for different samples. For Ar isotopic measurements, pure ${ }^{38} \mathrm{Ar}$ separated at the University of Bern, Switzerland, was used as a spike. The accuracy of the results was controlled by the analysis of the international GL-O glauconite standard (Odin et al., 1982); the deviations from the reference value were within $2 \%$ accuracy. The $\mathrm{K}$ contents were measured by a Sherwood 420 flame photometer; NBS 98a Plastic Clay $\left(1.04 \% \mathrm{~K}_{2} \mathrm{O}\right)$ was used as a standard to check that the errors did not surpass $\pm 0.02 \% \mathrm{~K}_{2} \mathrm{O}$, i.e. were within $2 \%$ accuracy. Standard errors, given with a $2 \sigma$ uncertainty, were calculated from the mathematical law of error propagation.

\section{RESULTS}

\section{PETROGRAPHY}

The sandstones studied are well-sorted, fine- to medium-grained sublithic arenites, with the exception of sample Jarocin-7 2792.3, which is a quartz-rich subarkose. The contents of lithic grains vary from $5 \%$ (of rock volume; Jarocin-7 2792.3 and Rokietnica-3 3665.8) to 18\% (Krzykosy-1A 3878.5). Lithic grains consist of fragments of volcanic and low-grade metamorphic rocks (metasandstones and metamudstones). The contents of feldspar grains fluctuate between $3 \%$ (Krzykosy-1A 3878.5, Lelików-6 1665.7) and 13\% (Kuźnica Grab. - two samples). Illite, hematite, and quartz are common diagenetic phases. Besides, calcite, dolomite, anhydrite, kaolinite, and chlorite occur in different samples. Porosities range from 18\% (Jarocin-7 2792.3) and 15\% (Lelików-6 1665.7 ) to 5\% (Rokietnica-3 3665.8) and 3\% (Krzykosy-1A 3878.5).

All samples contain grains with inherited clay minerals, which fill grain embayments and discontinuously coat the surfaces, and commonly are coloured red by fine hematite crystals. Such inherited clay minerals are common in aeolian sandstones of the Fore-Sudetic Monocline.

\section{SEM AND TEM OBSERVATIONS}

Authigenic illite observed in pores of the sandstones forms dense nets of interlocking crystals (Fig. 3A), sometimes resembling a boxwork texture (Fig. 3B). Some of these crystals bridge pore space, thus lower the sandstone permeability. Authigenic illite occurs also inside altered grains (Fig. 4A). Inherited clay minerals are well-recognizable in thin sections (Fig. 4A, B). Judging from their high potassium contents, they also show illitic composition.

SEM observations revealed two dominant illite morphologies: laths and flake-like particles (Fig. 3B, D, E). The latter result from the overlap of many illite laths (Fig. 3D, F), but possibly some grain-coating flakes show their natural habits (Fig. 3B, C). They are terminated by fine illite laths. Typical illite fibres, i.e. crystals with an aspect ratio $>100$, do not predominate among other morphological varieties. Sample Jarocin-7 2792.3 exhibits a distinctive texture: illite laths are arranged circularly forming tunnels of a 30-40 $\mu \mathrm{m}$ diameter (Fig. 3C). This arrangement may be an artefact caused by the collapse of clay minerals during air-drying; similar textures were observed, e.g., in experiments conducted by Nadeau (1998).

Authigenic minerals other than illite (dolomite, quartz, kaolinite, calcite) are also visible under SEM, although they are apparently scarcer than illite and usually form larger crystals. Fine authigenic K-feldspar crystals, $2-5 \mu \mathrm{m}$ in size, rimming empty voids after dissolved detrital grains, were noticed in sample Lelików-6 1665.7, but they are rare in the sample.

TEM observations confirmed the presence of well-crystallised, euhedral illite laths of various sizes and pseudohexagonal plates (Fig. 4C, D). Illite laths and their aggregates predominate, however, electron-dense phases, euhedral in shape, also occur in the samples. They are interpreted as hematite crystals and other authigenic minerals, but their mineralogy has not been analysed. Irregular or ragged grains typical of detrital particles have not been observed.

\section{XRD RESULTS}

Illite is the predominant mineral of the clay fraction in all the samples (Fig. 5). In addition to illite, minor amounts of chlorite and kaolinite occur in some samples (Table 1). Besides, in the $<2 \mu \mathrm{m}$ fractions, minor to trace amounts of quartz, hematite, albite, K-feldspar, dolomite, and barite were detected. The minerals other than illite and hematite decline in the $<0.2 \mu \mathrm{m}$ fractions.

"Illite" described in this contribution is not a pure, non-expandable, single mineral. It contains a small proportion of expandable layers as indicated by the $I r$ values in the range of $1.22-1.36$, the FWHM values in the range of $0.53-0.84$, and a slight change of the 001 reflections after EG treatment (they are slightly shifted and become narrower - Fig. 5). According to Eberl and Velde (1989) grid based on Ir and FWHM data, the content of swelling layers is in the range of $2-4 \%$. In turn, according to Środoń (1984) identification method of illitic materials, the clay minerals consist of a mixture of illite with ordered highly illitic illite/smectite (I/S); this I/S mineral does not show discrete reflections, so it is difficult for precise identification. The $\sim 10 \AA$ peaks for the air-dried $<2 \mu \mathrm{m}$ fractions are asymmetrical and biased towards small angles. Modelling their shapes with a mathematical function (Pearson split) reveals that they fit to the overlap of two reflections (one mineral of FWHM $\sim 1.0$ and the other of FWHM $\sim 0.4$ ). The $\sim 10 \AA$ reflections for the air-dried $<0.2 \mu \mathrm{m}$ fractions are wider and more symmetrical. On the basis of these observations, "illite" is regarded as a mixture of at least two phases. The interpretation of highly illitic I/S as very thin illite particles in the earliest stages of development has also been postulated in literature (e.g., Wilson et al., 2014), but it is not considered in the following text.

Only the $1 \mathrm{M}$ polytype was recognized; reflections characteristic of illite $2 M_{1}$ have not been detected. 

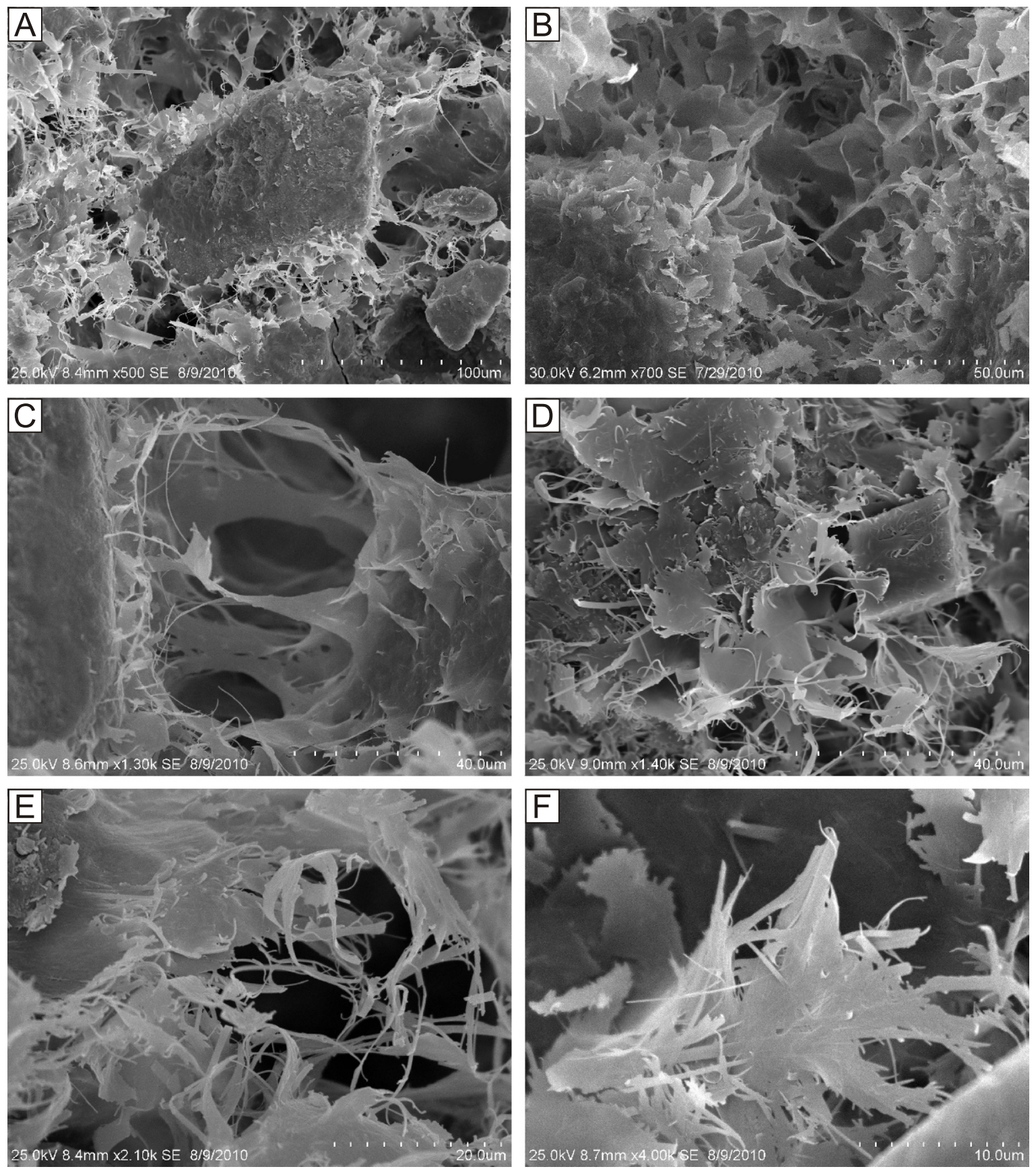

Fig. 3. SEM photomicrographs of authigenic illite in Rotliegend sandstones from the Fore-Sudetic Monocline

A - dense network of illite overgrowing detrital grain and bridging pore space; $\mathbf{B}$ - flakes and laths of grain-coating illite; C authigenic illite bridging a pore-throat and forming a tunnel-like texture; D - various habits of illite, illite laths overgrow a dolomite rhombohedron; $\mathbf{E}$ - illite laths at the ends of flake-shaped particles; F - cluster of illite laths; A, C, E - sample Jarocin-7 2792.3; B, D, F - sample Kuźnica Grab.-2 2259.4

K-Ar DATA

The $\mathrm{K}-\mathrm{Ar}$ data are presented in Table 2. The $\mathrm{K}_{2} \mathrm{O}$ contents vary between 5.99 and $3.23 \%$ and are distinctly lower than the $\mathrm{K}_{2} \mathrm{O}$ contents in illites from German Rotliegend sandstones (9.75-7.80\%; Clauer et al., 2012). This is caused by an admixture of other minerals and, possibly, by lower $\mathrm{K}$ contents in the studied illites than in German illites. These lower K contents are indicated by the higher FWHM values of the studied illites (the majority $>0.65$ ) as compared to German illites (the majority $<0.55$; Clauer et al., 2012). The radiogenic ${ }^{40} \mathrm{Ar}$ contents range from 81.4 to $43.7 \%$ of the total measured $\mathrm{Ar}$, which indicates relatively low atmospheric $\mathrm{Ar}$ contamination.

The K-Ar data scatter widely between $237.7 \pm 2.3$ and 148.8 $\pm 2.1 \mathrm{Ma}$. The former value (237.7) is not very reliable because of a weak signal-to-noise ratio during ${ }^{36} \mathrm{Ar}$ measurements. The majority of dates fall within the range between 195 and $150 \mathrm{Ma}$. A distinctive feature is the constant trend of increasing age with decreasing fraction sizes in individual samples. The age difference between the 2-0.5 and $<0.2 \mu \mathrm{m}$ size fractions is lowest for Rokietnica-3 3665.8 ( 10 m.y.) and Krzykosy-1A 3878.5 $(\sim 11$ m.y.) samples, and is as large as $\sim 50$ m.y. for Lelików-6 

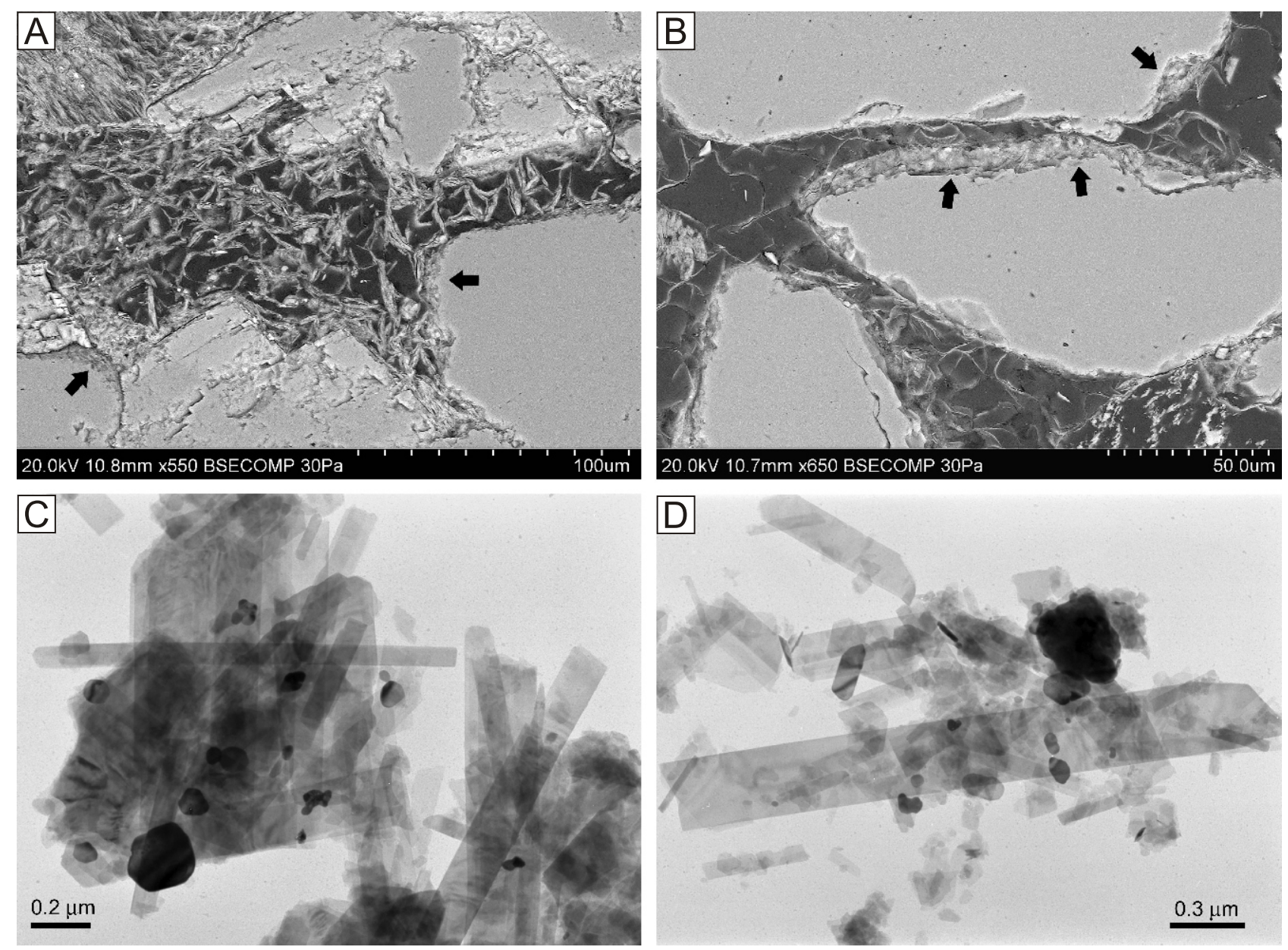

Fig. 4A, B - back-scattered electron images of authigenic illite and discontinuous inherited clay minerals of illitic composition (arrowed); C, D - TEM images of $<2 \mu \mathrm{m}$ fractions separated from Rotliegend sandstones

$\mathrm{C}, \mathrm{D}$ - euhedral illite laths of various sizes predominate in the samples; dark, electron-dense phases are also euhedral and are interpreted as authigenic minerals, primarily hematite; A and C - sample Krzykosy-1A 3878.5; B - sample Lelików-6 1665.7; D - sample Jarocin-7 2792.3

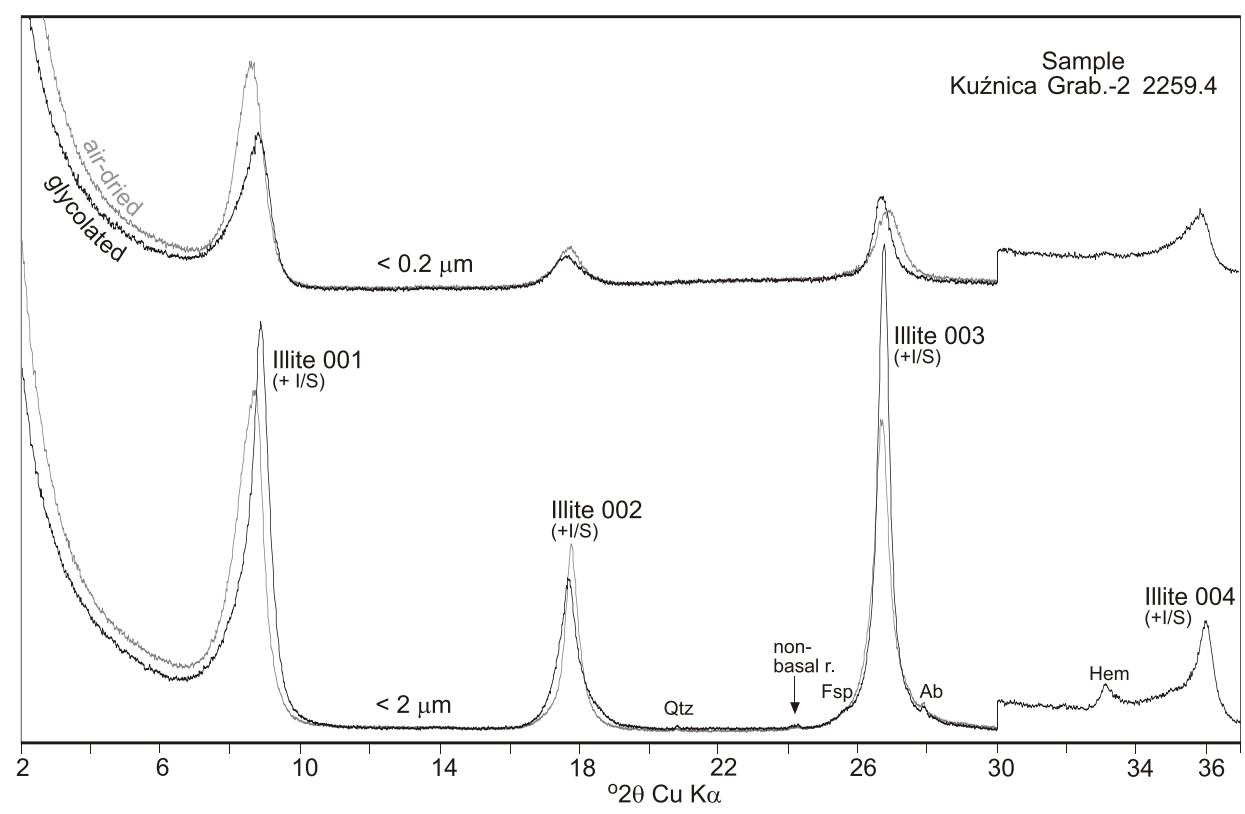

Fig. 5. Representative XRD patterns of two oriented size fractions ( $<2$ and $<0.2 \mu \mathrm{m}$ ) separated from Rotliegend sandstone of the Fore-Sudetic Monocline 
Mineralogy and illite data of clay minerals separated from Rotliegend sandstones of the Fore-Sudetic Monocline - based on XRD analyses

\begin{tabular}{|c|c|c|c|c|c|c|c|}
\hline \multirow{2}{*}{ Borehole } & \multirow{2}{*}{$\begin{array}{l}\text { Depth } \\
\text { [m] }\end{array}$} & \multirow{2}{*}{$\begin{array}{l}\text { Size } \\
\text { fractions }\end{array}$} & \multicolumn{2}{|c|}{ Clay minerals } & \multirow{2}{*}{$\begin{array}{l}\text { Non-clay minerals } \\
\text { (minor to trace) }\end{array}$} & \multirow{2}{*}{$\begin{array}{c}\text { FWHM } \\
\text { Illite } 001 \\
\Delta^{\circ} 2 \theta\end{array}$} & \multirow{2}{*}{$\begin{array}{l}\text { Illite } \\
\text { Ir }\end{array}$} \\
\hline & & & Illite & Others & & & \\
\hline Rokietnica-3 & 3665.8 & $<2 \mu \mathrm{m}$ & predominant & chlorite, $<5 \%$ & Hem, Qtz, Fsp & 0.70 & 1.31 \\
\hline Krzykosy-1A & 3878.5 & $<2 \mu \mathrm{m}$ & predominant & chlorite, $<5 \%$ & Hem, Qtz, Ab & 0.53 & 1.22 \\
\hline \multirow{2}{*}{ Jarocin-7 } & \multirow{2}{*}{2792.3} & $<2 \mu \mathrm{m}$ & predominant & chlorite, $15 \%$ & Hem, Qtz, Fsp, Bar & 0.66 & 1.36 \\
\hline & & $<0.2 \mu \mathrm{m}$ & predominant & - & Hem & - & - \\
\hline \multirow{2}{*}{ Kuźnica Grab.-2 } & \multirow{2}{*}{2259.4} & $<2 \mu \mathrm{m}$ & predominant & - & Hem, Qtz, Fsp & 0.84 & 1.32 \\
\hline & & $<0.2 \mu \mathrm{m}$ & predominant & - & Hem & - & - \\
\hline \multirow{2}{*}{ Kuźnica Grab.-2 } & \multirow{2}{*}{2242.5} & $<2 \mu \mathrm{m}$ & predominant & - & Qtz, Fsp & 0.67 & 1.23 \\
\hline & & $<0.2 \mu \mathrm{m}$ & predominant & - & - & - & - \\
\hline \multirow[t]{2}{*}{ Lelików-6 } & \multirow[t]{2}{*}{1665.7} & $<2 \mu \mathrm{m}$ & predominant & kaol., chlorite & $\begin{array}{l}\text { Hem, K-Fsp, Ab, } \\
\text { Qtz, Dol }\end{array}$ & 0.73 & 1.33 \\
\hline & & $<0.2 \mu \mathrm{m}$ & predominant & kaolinite & Hem & - & - \\
\hline
\end{tabular}

Ab - albite, Bar - barite, Dol - dolomite, Fsp - feldspar, Hem - hematite, Qtz - quartz

1665.7 sample. Two samples taken from the same borehole in a distance of 17 m (Kuźnica Grab.-2 2242.5 and Kuźnica Grab.-2 2259.4) yielded slightly shifted data (155.4 \pm 1.8 and $148.8 \pm 2.1 \mathrm{Ma}$ for the $2-0.5 \mu \mathrm{m}$ fraction) but with the similar age difference between the coarse and fine fractions of $\sim 35$ m.y. Any obvious differences have been noticed between the results obtained for the sandstones from the Eastern Erg and the Southern Erg.

\section{DISCUSSION}

The available K-Ar data of illite from Rotliegend aeolian sandstones from the Fore-Sudetic Monocline are summarized in Table 2 and depicted on Figure 6. Michalik's (2001) data concern the uppermost, not redden part of Middle Permian clastic rocks called "Weissliegend".

The majority of samples from the Fore-Sudetic Monocline show different ages for various particle size fractions, which is in a marked contrast to a narrow age spectrum for various size fractions of illite from Rotliegend sandstones in northern Germany (Zwingmann et al., 1999; Liewig and Clauer, 2000; Clauer et al., 2012). The uniform K-Ar results for various particle size fractions separated from German Rotliegend sandstones indicate isotropic homogeneity of illite and are interpreted as geologically meaningful ages of short-lasting hydrothermal events, during which illite rapidly grew (Zwingmann et al., 1999; Liewig and Clauer, 2000; Clauer et al., 2012). Indeed, the fibrous morphology of illite is often considered as an indication of its rapid growth (Wilkinson and Haszeldine, 2002; Lander and Bonnell, 2010).

\section{JURASSIC AGES}

Two of the six samples in the present study yielded a relatively narrow dispersion of K-Ar data for different size fractions. Illite from Rokietnica-3 3665.8 sample was dated for 185-195 Ma whereas illite from Krzykosy-1A 3878.5 sample was dated for $\sim 165-175 \mathrm{Ma}$. Similar results were obtained also in other studies concerning the Rotliegend of the Fore-Sudetic Monocline. Different size fractions of illite separated from two
Witowo-1 sandstones yielded almost identical $\mathrm{K}-\mathrm{Ar}$ data to those of Krzykosy-1A 3878.5 sample (Protas et al., 2006; Maliszewska and Kuberska, 2009). Both boreholes, Krzykosy-1A and Witowo-1, are located nearby (Fig. 1). The $\sim 165 \mathrm{Ma}$ age was obtained also for the $<0.2 \mu \mathrm{m}$ size fraction from Komorze-2 4223.7 sample (Maliszewska and Kuberska, 2009) and for three $<0.2 \mu \mathrm{m}$ size fractions from sandstones from the Sieroszowice, Lubin, and Rudna copper mines (Michalik, 2001). The similar ages of several different size fractions found for three different samples and for the fine fractions of further four samples is a convincing argument for a geologically meaningful age of a crystallisation episode (Clauer and Chaudhuri, 1995). The same concerns the older age ( 185-195 Ma). It was noted for three size fractions of Rokietnica-3 3665.8 sample, for two fractions $(<0.2$ and $0.2-0.5 \mu \mathrm{m}$ ) of Kuźnica Grabowska-2 2242.5 sample (this study), and for the $<0.2 \mu \mathrm{m}$ fractions separated from sandstones from the Polkowice and Rudna copper mines (Michalik, 2001). A similar age (190-216 Ma) was estimated for diagenetic illite in the copper-mineralised Kupferschiefer of the Fore-Sudetic Monocline and interpreted as a time of migration of ore-forming brines (Bechtel et al., 1999). Also, the whole-rock $\mathrm{K}-\mathrm{Ar}$ dating of altered andesite from the western part of the Fore-Sudetic Monocline yielded 188-191 $\pm 2 \mathrm{Ma}$, interpreted as an age of rock alteration under sub-greenschist facies (Bylina, 2006).

The third Jurassic signal which can be tentatively recognized among the available data is that around $150 \mathrm{Ma}$. Yet its meaning is unclear because three in four samples show large spread of data. Therefore, it as well may be a random age.

The two age ranges, $\sim 185-195 \mathrm{Ma}$ and $\sim 165-175 \mathrm{Ma}$, can be interpreted as two pulses of intense illite growth in the area of the Fore-Sudetic Monocline. This growth was so intense and high-temperature that any further diagenetic process or later fluid flows have not blurred it. Present-day temperatures at the burial depth of the Rotliegend sandstones ( 3700-3900 m) approximate $130-140^{\circ} \mathrm{C}$ and have not reset the Jurassic signals, although any increase of temperature beyond that of illite crystallisation affects the K-Ar signature of illite, i.e. lowers its age (Clauer and Chaudhuri, 1995; Clauer, 2013). Therefore, the Jurassic age signals provide evidence that temperatures in 
Available K-Ar ages of authigenic illite from Rotliegend aeolian sandstones of the Fore-Sudetic Monocline

\begin{tabular}{|c|c|c|c|c|c|c|c|c|}
\hline Borehole & $\begin{array}{c}\text { Depth } \\
\text { [m] }\end{array}$ & Location & Size $[\mu \mathrm{m}]$ & $\begin{array}{c}\mathrm{K}_{2} \mathrm{O}[\%] \\
\mathrm{K}[\%]\end{array}$ & $\begin{array}{c}{ }^{40} \mathrm{Ar}^{*} \\
{[\%]}\end{array}$ & $\begin{array}{c}{ }^{40} \mathrm{Ar}^{*} \\
{[\mathrm{pmol} / \mathrm{g}]}\end{array}$ & $\begin{array}{c}\text { Age } \\
{[\mathrm{Ma} \pm 2 \sigma]}\end{array}$ & $\begin{array}{c}\text { Source/ } \\
\text { Laboratory }\end{array}$ \\
\hline \multirow{3}{*}{ Rokietnica-3 } & \multirow{3}{*}{3665.8} & \multirow{3}{*}{ EE } & $2-0.5$ & 4.34 & 61.5 & 1214.8 & $184.7( \pm 2.7)$ & \multirow{18}{*}{$\begin{array}{c}\text { this study } \\
\text { P.A.S. Cracow, } P L\end{array}$} \\
\hline & & & $0.5-0.2$ & 5.99 & 74.7 & 1694.5 & $186.6( \pm 1.5)$ & \\
\hline & & & $<0.2$ & 5.31 & 75.8 & 1573.7 & $195.0( \pm 1.7)$ & \\
\hline \multirow{3}{*}{ Krzykosy-1A } & \multirow{3}{*}{3878.5} & \multirow{3}{*}{ EE } & $2-0.5$ & 4.78 & 57.9 & 1170.4 & $162.6( \pm 2.1)$ & \\
\hline & & & $0.5-0.2$ & 5.01 & 66.7 & 1263.3 & $167.2( \pm 2.0)$ & \\
\hline & & & $<0.2$ & 5.29 & 67.8 & 1391.5 & $174.1( \pm 1.8)$ & \\
\hline \multirow{3}{*}{ Jarocin-7 } & \multirow{3}{*}{2792.3} & \multirow{3}{*}{ EE } & $2-0.5$ & 4.46 & 43.7 & 1166.0 & $173.1( \pm 4.6)$ & \\
\hline & & & $0.5-0.2$ & 5.01 & 71.0 & 1474.7 & $193.7( \pm 2.4)$ & \\
\hline & & & $<0.2$ & 4.73 & 68.4 & 1528.6 & $211.6( \pm 3.0)$ & \\
\hline \multirow{3}{*}{ Kuźnica Grab.-2 } & \multirow{3}{*}{2259.4} & \multirow{3}{*}{ SE } & $2-0.5$ & 5.72 & 52.6 & 1277.2 & $148.8( \pm 2.1)$ & \\
\hline & & & $0.5-0.2$ & 5.20 & 79.5 & 1191.9 & $152.6( \pm 2.0)$ & \\
\hline & & & $<0.2$ & 5.85 & 81.4 & 1607.3 & $181.4( \pm 1.6)$ & \\
\hline \multirow{3}{*}{ Kuźnica Grab.-2 } & \multirow{3}{*}{2242.5} & \multirow{3}{*}{ SE } & $2-0.5$ & 5.32 & 60.2 & 1243.1 & $155.4( \pm 1.8)$ & \\
\hline & & & $0.5-0.2$ & 4.36 & 61.9 & 1244.7 & $188.2( \pm 2.1)$ & \\
\hline & & & $<0.2$ & 4.83 & 59.4 & 1423.1 & $193.9( \pm 2.6)$ & \\
\hline \multirow{3}{*}{ Lelików-6 } & \multirow{3}{*}{1665.7} & \multirow{3}{*}{ SE } & $2-0.5$ & 4.52 & 74.4 & 1285.9 & $187.6( \pm 1.9)$ & \\
\hline & & & $0.5-0.2$ & 3.23 & 47.7 & 1068.0 & $216.2( \pm 3.9)$ & \\
\hline & & & $<0.2$ & 4.32 & 78.1 & 1579.6 & $237.7( \pm 2.3)$ & \\
\hline \multirow{2}{*}{ Pniewy-1 } & 36045 & $\mathrm{FF}$ & $<0.3$ & 7.28 & 49.6 & 1430 & $109.5( \pm 3.1)$ & \\
\hline & 3004.0 & ㄷ & $<0.2$ & 4.44 & 42.0 & 1310 & $113.6( \pm 3.6)$ & \\
\hline Obiezierze IG1 & & & $<0.3$ & 4.73 & 48.1 & 1116 & $131.1( \pm 3.8)$ & \\
\hline Unjezlerze ivi & $4 \angle 21.6$ & ㄷ & $<0.2$ & 4.60 & 46.3 & 1251 & $150.4( \pm 4.5)$ & \\
\hline & 4525.3 & $E E$ & $<0.3$ & 6.41 & 51.8 & 1273 & $110.0( \pm 3.0)$ & Kuberska (2009) \\
\hline vVrzesnia I I & $45<0.3$ & ㄷ & $<0.2$ & 5.91 & 48.4 & 1229 & $116.1( \pm 3.3)$ & Isotope Geoscience \\
\hline & & & $<0.3$ & 6.21 & 51.5 & 1643 & $146.4( \pm 4.0)$ & \\
\hline Sroda IG3 & 3854.3 & EE & $<0.2$ & 5.87 & 65.4 & 1645 & $154.7( \pm 3.7)$ & \\
\hline & & & $<0.3$ & 5.60 & 37.1 & 1307 & $129.7( \pm 4.5)$ & \\
\hline Florentyna IGZ & 3381.0 & EE & $<0.2$ & 5.22 & 48.9 & 1273 & $135.4( \pm 3.9)$ & \\
\hline & & & $<0.3$ & 6.16 & 94.0 & & $172.7( \pm 0.9)$ & \\
\hline WVItowo-1 & 3613.3 & EE & $<0.2$ & 5.87 & 94.0 & & $173.1( \pm 1.2)$ & \\
\hline & & & $<0.3$ & 8.64 & 95.0 & & $131.1( \pm 1.3)$ & Kuberska (2009) \\
\hline Komorze-2 & 4223.1 & EE & $<0.2$ & 6.69 & 95.0 & & $165.4( \pm 1.2)$ & Institute of Physics \\
\hline & & & $<0.3$ & 5.89 & 93.0 & & $156.8( \pm 1.3)$ & \\
\hline Gołuchow-2 & 3185.1 & EE & $<0.2$ & 5.30 & 93.0 & & $172.5( \pm 1.6)$ & \\
\hline & & & $2-0.2$ & 3.63 & 83.5 & 1369 & $205.2(1 \sigma<1 \%)$ & \\
\hline Kórnik-2 & 4221.1 & EE & $0.2-0.05$ & 5.12 & 86.4 & 1779 & $190.1 \quad \downarrow$ & \\
\hline & & & $<0.02$ & 5.37 & 87.8 & 1760 & 179.8 & \\
\hline & & & $2-0.2$ & 2.87 & 87.3 & 1300 & 243.1 & \\
\hline Polwica-1 & 36881 & $\mathrm{FF}$ & $0.2-0.05$ & 4.40 & 88.4 & 1761 & 216.6 & \\
\hline Polwica-1 & 3080.1 & EE & $0.05-0.02$ & 4.85 & 87.8 & 1847 & 207.8 & \\
\hline & & & $<0.02$ & 5.52 & 88.1 & 1926 & 191.2 & Protas et al. (2006) \\
\hline & & & $2-0.2$ & 4.56 & 95.3 & 2283 & 276.5 & Institute of Physics \\
\hline Krzykosy-1A & 38829 & $\mathrm{FF}$ & $0.2-0.05$ & 5.97 & 92.7 & 2386 & 196.0 & UMCS Lublin, PL \\
\hline Krzykosy-TA & 3882.9 & EE & $0.05-0.02$ & 6.36 & 91.2 & 2158 & 197.7 & \\
\hline & & & $<0.02$ & 6.63 & 93.0 & 2257 & 221.4 & \\
\hline & & & $2-0.2$ & 3.86 & 91.0 & 1159 & 165.5 & \\
\hline & & & $0.2-0.05$ & 5.30 & 85.1 & 1687 & 174.8 & \\
\hline Witowo-1 & 3903.1 & EE & $0.05-0.02$ & 4.99 & 89.7 & 1583 & 174.4 & \\
\hline & & & $<0.02$ & 5.51 & 90.8 & 1663 & 166.1 & \\
\hline
\end{tabular}


Tab. 2 cont.

\begin{tabular}{|c|c|c|c|c|c|c|c|c|}
\hline Sample & $\begin{array}{l}\text { Depth } \\
\text { [m] }\end{array}$ & Location & Size $[\mu \mathrm{m}]$ & $\mathrm{K}_{2} \mathrm{O}[\%]$ & $\begin{array}{l}{ }^{40} \mathrm{Ar}^{*} \\
{[\%]}\end{array}$ & $\begin{array}{c}{ }^{40} \mathrm{Ar}^{*} \\
{[\mathrm{pmol} / \mathrm{g}]}\end{array}$ & $\begin{array}{c}\text { Age } \\
{[\mathrm{Ma} \pm 2 \sigma]}\end{array}$ & $\begin{array}{c}\text { Source/ } \\
\text { Laboratory }\end{array}$ \\
\hline Rudna N & & SE & $<0.2$ & 6.23 & 93.4 & & $166.2( \pm 4.1) 1 \sigma$ & \multirow{5}{*}{$\begin{array}{l}\text { Michalik (2001) } \\
\text { Institute of Physics } \\
\text { UMCS Lublin, PL }\end{array}$} \\
\hline Rudna Główna & & SE & $<0.2$ & 4.93 & 72.6 & & $186.2( \pm 4.2) \downarrow$ & \\
\hline Lubin W & & SE & $<0.2$ & 5.76 & 69.7 & & $163.7( \pm 3.8)$ & \\
\hline Sieroszowice & & SE & $<0.2$ & 5.56 & 69.9 & & $158.8( \pm 3.6)$ & \\
\hline Polkowice W & & SE & $<0.2$ & 5.94 & 95.6 & & $181.3( \pm 5.3)$ & \\
\hline
\end{tabular}

${ }^{*} \mathrm{Ar}$ - radiogenic Ar; EE - Eastern Erg; SE - Southern Erg

Rotliegend sandstones were higher in the Jurassic than at present - at least at places. This is in complete accord with the assumed high to regionally maximum burial and enhanced heat flow in the Jurassic (Karnkowski, 1999; Botor et al., 2013). However, there are some premises that high temperatures were not attained solely due to burial, but were an effect of hot fluid flows, i.e. some heating events. The data are recorded only locally; they are grouped in few time intervals, and the same intervals were documented in frequent studies concerning Rotliegend and other rocks in Central and Western Europe (see next para- graph). Second, the crystallisation of illite has been interpreted as concomitant with the flow of copper-bearing brines (Bechtel et al., 1999; Michalik, 2001). Moreover, Bylina (2006) suggested that hydrothermal fluids that caused the alteration of Permian mafic rocks in the western part of the Fore-Sudetic Monocline flowed episodically, some in the Early Jurassic. Finally, if part of illite had formed from a smectite precursor, which could be deduced from the occurrence of highly illitic $\mathrm{I} / \mathrm{S}$, then the temperature of illitisation might have been above $160^{\circ} \mathrm{C}$ (Pollastro, 1993; Środoń, 2007).

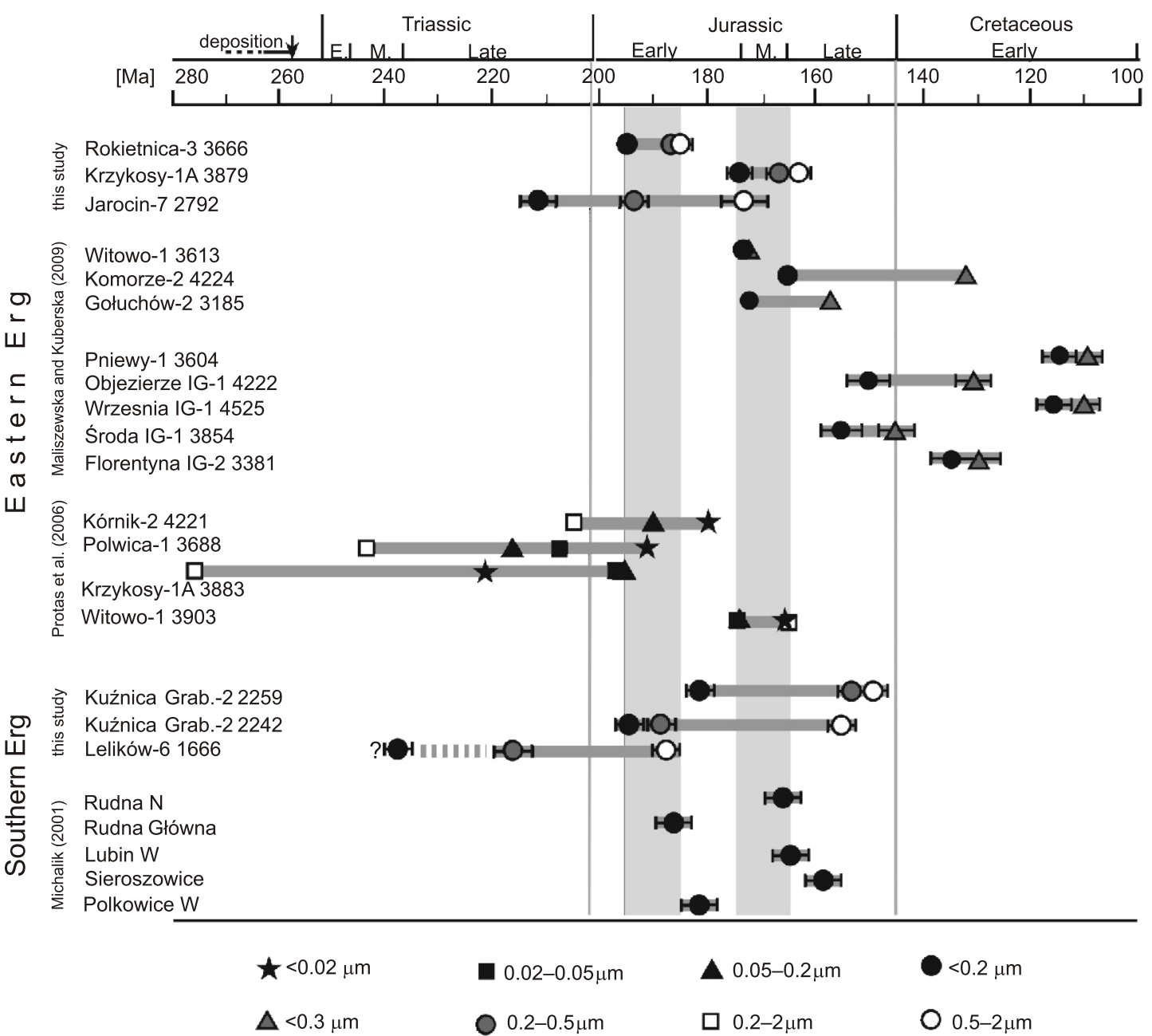

Fig. 6. Graphical representation of the available K-Ar ages of authigenic illite from Rotliegend sandstones of the Fore-Sudetic Monocline

Data from Michalik (2001), Protas et al. (2006), Maliszewska and Kuberska (2009), and from this study; samples are grouped according to geographical location and laboratories in which measurements were performed (see also Table 2); two vertical grey bars represent two periods of suggested enhanced activity of illite growth 


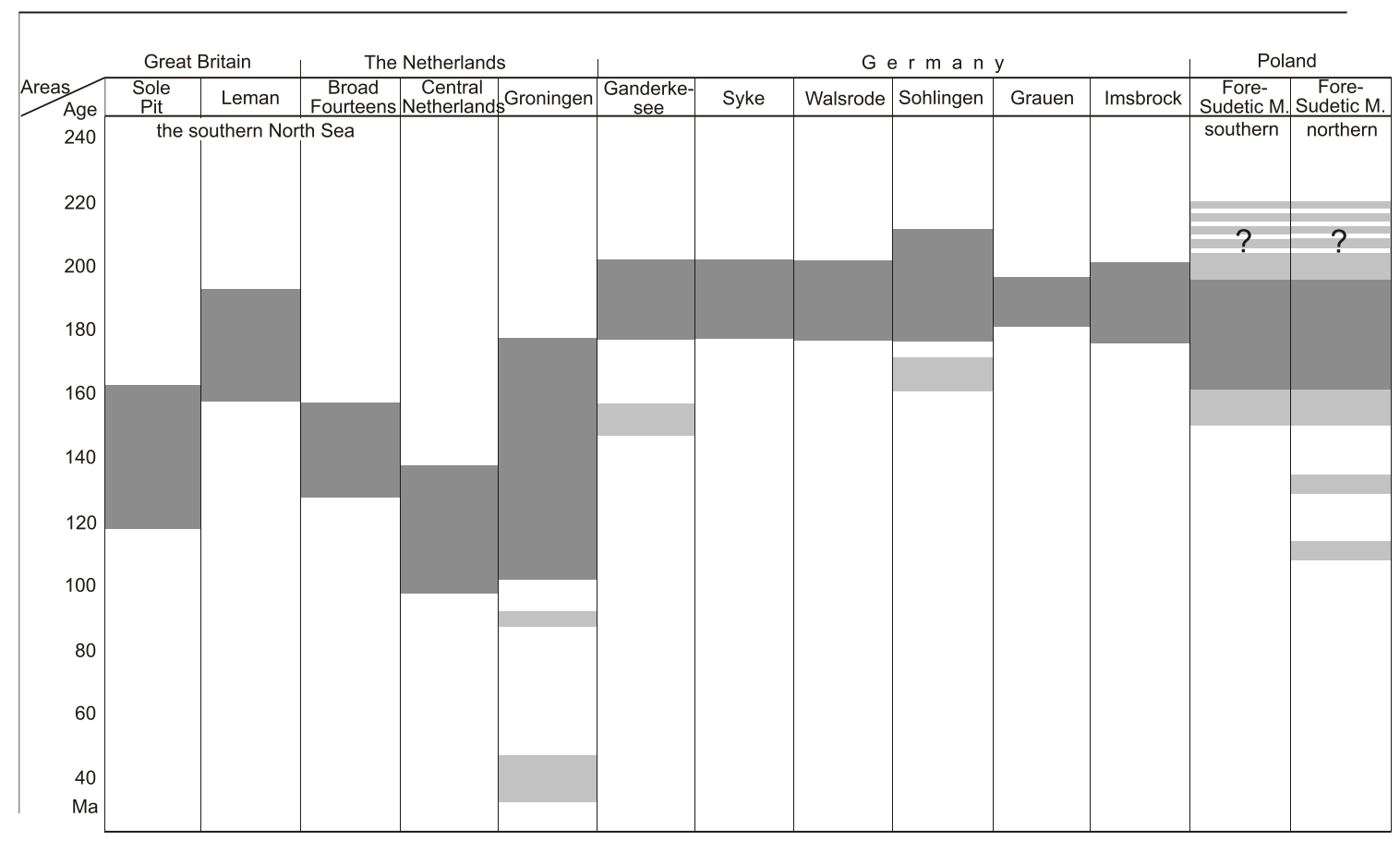

Fig. 7. Comparison of K-Ar ages of authigenic illite in Rotliegend sandstones from Western-Central Europe (after Clauer et al., 2012 completed with the data from the Fore-Sudetic Monocline)

The light grey bars denote individual ages; data from: Lee et al. (1985), Platt (1993), Ziegler et al. (1994), Zwingmann et al. (1999), Liewig and Clauer (2000), Michalik (2001), Protas et al. (2006), Maliszewska and Kuberska (2009), Clauer et al. (2012), this study

The Jurassic thermal events are not restricted only to the area of the Fore-Sudetic Monocline but they are widespread throughout Western and Central Europe (Fig. 7), indicating large-scale underlying processes. The older signal ( 180-200 Ma) has been frequently noted in Rotliegend sandstones of northern Germany (Platt, 1993; Clauer et al., 1996, 2012; Zwingmann et al., 1998, 1999; Liewig and Clauer, 2000; Fischer et al., 2012); it is known also from some Rotliegend sandstones of the southern North Sea (Ziegler et al., 1994). Moreover, Triassic sandstones of the Paris Basin (Mossmann et al., 1992) and northern Africa (Clauer et al., 1996) recorded 190 Ma hydrothermal activity. Carboniferous sandstones from central Poland (the Mazowsze region) also bear signals of a 200 Ma hydrothermal event (Kozłowska and Poprawa, 2004). The younger signal $(\sim 165-175 \mathrm{Ma})$ is also clearly recorded in Rotliegend sandstones of Central Europe (northern Germany, Zwingmann et al., 1999; Clauer et al., 2012) and Western Europe (southern North Sea, Lee et al., 1989; Robinson et al., 1993; Ziegler et al., 1994). Środoń et al. (2006) found a $\sim 175$ Ma thermal event superimposed on burial diagenesis of Carboniferous rocks of the Upper Silesian Coal Basin, southern Poland, and Kozłowska and Poprawa (2004) dated illite in one sample of Carboniferous sandstone of central Poland for $\sim 165 \mathrm{Ma}$. In turn, a 150 Ma heating event has been well-documented in hydrothermal deposits in the Black Forest, Germany (Meyer et al., 2000), and at the basin/basement unconformity in western France (Cathelineau et al., 2012). Palaeomagnetic measurements of the Cu-bearing Kupferschiefer in eastern Germany yielded a Late Jurassic palaeopole at $\sim 150 \mathrm{Ma}$, interpreted as extensive activity of hydrothermal fluids (Symons et al., 2011).

The majority of authors suggested enhanced heat pulses before the opening of the Atlantic Ocean as a major trigger for hot fluid flows and illite crystallisation (Bonhomme et al., 1983; Mossmann et al., 1992; Robinson et al., 1993; Clauer et al., 1996; Zwingmann et al., 1998, 1999; Liewig and Clauer, 2000; Środoń et al., 2006). Gaupp et al. (1993) indicated increased tectonic activity before the opening of the Atlantic Ocean, which caused the reactivation of faults and facilitated fluid migration. Zwingmann et al. (1999) noticed that illitisation in Rotliegend sandstones of northern Germany occurred discontinuously and suggested three periods of enhanced illite growth (210-205, 200-175, 170-165 Ma).

\section{A DECREASING AGE WITH INCREASING PARTICLE-SIZE FRACTIONS}

All samples studied in this contribution show an inverse age trend with fraction sizes, i.e. the coarser fractions $(0.5-2 \mu \mathrm{m})$ are $\sim 10-50$ m.y. younger than the finer fractions $(<0.2 \mu \mathrm{m})$. Most probably, this is not produced by analytical errors, as similar results were yielded also in other studies and by other laboratories (Table 2). Even minor differences in size fractions (e.g., $<0.2$ and $<0.3 \mu \mathrm{m}$ in Maliszewska and Kuberska, 2009) may result in different $\mathrm{K}-\mathrm{Ar}$ data, and the finer fraction is older than the coarser one. Such a trend excludes contamination by detrital $\mathrm{K}$-bearing phases because the latter are usually concentrated in coarser fractions (e.g., Hamilton et al., 1989; Bechtel et al., 1999; Clauer, 2013). The only obvious contamination by detrital K-bearing material is noticed for sample Krzykosy-1A 3882.9 examined by Protas et al. (2006): the K-Ar date of the $<2 \mu \mathrm{m}$ fraction $(276.5 \pm 2.7 \mathrm{Ma})$ is evidently older than the depositional age ( 260-270 Ma; the deposition of the Kupferschiefer is constrained at $258 \pm 2 \mathrm{Ma}$; Menning et al., 2006; cf. Peryt et al., 2012). This explains the discrepancy between the results obtained by Protas et al. (2006) and in the present study for samples taken from the same borehole at similar depths (Table 2). 
The K-Ar data of Protas et al. (2006) are presented in an abstract, so any supportive material is not included, neither analytical details, nor XRD data and TEM micrographs. Therefore, the results obtained from another sample analysed by Protas et al. (2006), Polwica-1 3688.1, which show a normal age trend with increasing size fractions and an exceptionally old age for the $2-0.2 \mu \mathrm{m}$ fraction $(241.1 \mathrm{Ma})$, seem problematic on the basis of the available data.

The age dispersion in individual samples can result from long-lasting illite growth, either continuous or in pulses (e.g., Lee et al., 1989; Clauer et al., 1997; Środoń et al., 2006). The inverse age trend, however, contradicts the common assumption that the finest fraction of fibrous illite represents the last formed illite (Lee et al., 1989; Hamilton et al., 1989). On the other hand, Lander and Bonnell (2010) state recently that "the extent to which the smallest illite fraction actually represents the last formed illite is unclear". Taking into account the observation that the illitic material in the samples may be a mixture of at least two phases (illite and highly illitic illite/smectite), a multistage illitisation process, including illitisation of a smectite precursor and the growth of fibrous illite, is highly probable. In such a case the crystal size distribution is different than it would be in the case of pure fibrous illite which crystallised directly from solution. Besides, it is not clear how inherited clay minerals affect the $\mathrm{K}-\mathrm{Ar}$ ages. If these clay minerals had been originally smectitic, which is probable in an aeolian environment, then they would represent (part of?) the illite/smectite admixture. The presence of early diagenetic smectite cement is also a probable option. Since illite/smectite is more fine-grained in comparison with illite and tends to accumulate in finer fractions (Środoń, 1984), the older ages may be attributed to a stage of smectite illitisation.

Theoretically, a final stage might have also proceeded via the Ostwald ripening process (large particles growing at the expense of dissolving small particles), but this process has not been documented for illite. The increasing age with decreasing particle sizes has been observed for K-bentonites (Clauer et al., 1997; Środoń et al., 2002, 2006) and explained in such a way that during smectite illitisation coarser illite crystals grow from small nuclei by surface-controlled growth, and some small nuclei simply stop growing at an early stage (Środoń et al., 2000).

The inverse trend can be also explained by the contamination of the coarser fractions by an authigenic K-bearing phase other than illite. This cannot be completely rejected since small, authigenic K-feldspar was noted in sample Lelików-6 1665.7. Although such authigenic feldspar has not been observed in other samples, minor amounts of feldspar have been detected by XRD in the coarser fractions of a few other samples (Table 1). Nevertheless, if it were the case, the data would correspond to a diagenetic process, i.e. the crystallisation of K-feldspar from saline, K-rich solutions. Besides, observations by Ziegler (2006) and Fischer et al. (2012) from the southern North Sea and Germany indicate that the crystallisation of K-feldspar was synchronous with the crystallisation of fibrous illite.

\section{TRIASSIC AND CRETACEOUS AGES}

One cannot exclude that illitisation started in the Triassic, as suggested by a few Triassic ages, however the documentation for these ages is problematic - they were found for the fine fractions of only two samples which, besides, show the largest age scatter, and for samples examined by Protas et al. (2006), which are suspected to be biased by detrital contamination. Therefore, the oldest, Triassic stage, should be treated as largely unrecognized.
In turn, the youngest ages, Early Cretaceous ( 110-135 Ma), recorded for four Rotliegend sandstones of the Eastern Erg (Maliszewska and Kuberska, 2009), are much more concise. Their geological meaning is not entirely clear. They may correspond directly to the time of illite crystallisation (Maliszewska and Kuberska, 2009), which implies that the Jurassic stage of illitisation was not ubiquitous in the entire area of the Fore-Sudetic Monocline and that the growth of illite was displaced in time in the northern part of this area. However, two of these four samples (Objezierze IG1 4221.6, Września IG1 4525.3) come from the areas which, according to the numerical modelling of organic matter maturity (Botor, 2011), experienced maximum temperatures in the Late Cretaceous. In consequence, the Early Cretaceous ages of these two samples may as well be partially reset K-Ar Jurassic data, or mixed ages between the Jurassic and Late Cretaceous. Thus, the extent and the meaning of the Cretaceous ages of illite of the Fore-Sudetic Monocline are to be recognized in more detail.

Early Cretaceous dates were obtained also for Rotliegend samples from the Central Netherlands Basin (Lee et al., 1989) and some areas of the southern North Sea (Ziegler et al., 1994), and interpreted as the time of illite growth. However, Rotliegend sandstones in those areas besides illite contain randomly interstratified I/S (Ziegler, 2006), which indicates that they experienced lower temperatures than the Rotliegend of the Fore-Sudetic Monocline, and that the thermal evolutions of both areas were different.

\section{IMPLICATIONS FOR A PETROLEUM SYSTEM}

Recently, several 1D hydrocarbon generation models (Karnkowski, 1999; Kotarba et al., 2006; Botor, 2011; Botor et al., 2013) and a 3D gas migration model (Botor et al., 2013) have been prepared for sedimentary rocks of the Polish Rotliegend basin. According to these models, gas generation and migration which led to the filling of numerous reservoirs lasted from the Late Triassic to the Late Jurassic, and the main phase took place between the Late Triassic and the Early Jurassic. A second, minor and local episode occurred in the Late Cretaceous. In turn, the available K-Ar data suggest that the main phase of illite growth in the area of the Fore-Sudetic Monocline took place in the Jurassic. Later and minor illitisation might have occurred in the Cretaceous. Taking into account the general coincidence between the time of gas generation and migration, and the time of illite crystallisation, we may conclude that the same underlying processes which caused illitisation triggered also hydrocarbon migrations, or that hydrocarbon migrations triggered fluid flows and illite crystallisation.

Since hydrocarbon modelling needs a number of assumptions, such as heat flow values in ancient geological epochs and the thickness of eroded rocks, and it disregards advective heat transport or cementation processes (e.g., Botor et al., 2013), the results can be viewed only on a probability scale. It seems that better understanding of illitisation in Rotliegend sandstones should provide further insights into a petroleum system. The majority of data obtained so far come from water-saturated sandstones although Lee et al. (1985) showed that illite in the water zone may grow longer than in the gas zone. Careful sampling of gas-bearing intervals along with water-saturated sandstones and further careful K-Ar datings of authigenic illite are needed to clarify whether illitisation was continuous or episodic, synchronous throughout the area of the Fore-Sudetic Monocline or displaced in time, occurred due to burial only or was triggered by "exotic" fluids. 
The deleterious influence of fibrous illite on reservoir properties of sandstones is well-recognized. It is important to bear in mind, however, that even the massive growth of illite does not necessarily imply the blockage of gas migration. The growth of authigenic illite in Rotliegend sandstones of the Northwest German Basin was almost synchronous throughout that basin and well-constrained at (Early) Jurassic time (Zwingmann et al., 1998, 1999; Liewig and Clauer, 2000; Clauer et al., 2012). Yet a thorough basin modelling study of the German Rotliegend gas play (Schwarzer and Littke, 2007) revealed that the gas migration and filling of Rotliegend reservoirs proceeded for a long time, from the Late Permian until the Neogene, via a system of faults.

\section{RELATION TO OTHER DIAGENETIC PROCESSES}

Textural observations suggest that illite is one of the latest diagenetic phases occurring in the Rotliegend sandstones. It follows that hematite, dolomite and chlorite crystallised before the Jurassic, during the Late Permian and/or the Triassic. It is probable that smectite which was a precursor for a part of illite formed in the Late Permian/Early Triassic. Also compaction was completed before the illite growth, i.e. before the Jurassic. In turn, calcite and anhydrite, and part of quartz are the minerals that locally postdate the crystallisation of illite.

\section{CONCLUSIONS}

The available K-Ar data of authigenic illite separated from Rotliegend aeolian sandstones of the Fore-Sudetic Monocline were summarised and reviewed in terms of their geological meaning. The K-Ar data scatter widely between 276.5 and 109.5 Ma but only part of the results are meaningful and may be interpreted in terms of real geological processes.

The majority of ages are in the range between 195 and $150 \mathrm{Ma}$, i.e. they correspond to Jurassic times. The results may be grouped in several time intervals which are almost identical to those identified for Rotliegend sandstones of Central and Western Europe. Therefore, it is tentatively suggested that the Jurassic crystallisation of illite - similarly as in the area of northern Germany - proceeded in pulses rather than continuously, and was caused by episodic hot fluid flows rather than due to burial only. These pulses might have been triggered throughout the entire Southern Permian Basin by the same, large-scale underlying processes.
A few Early Cretaceous ages obtained from sandstones from the northern part of the Fore-Sudetic Monocline suggest that the growth of illite lasted longer than solely Jurassic times.

There are clear differences between the illite data from Rotliegend sandstones of Germany and Poland. In comparison with the non-swelling, isotopically homogeneous illite in German Rotliegend reservoirs, illite in aeolian Rotliegend sandstones of the Fore-Sudetic Monocline shows slightly swelling behaviour and, frequently, different ages for various particle-size fractions. These characteristics are interpreted as the occurrence of a mixture of illite and highly illitic illite-smectite, and a long illitisation process which included the crystallisation of illite from solution and, possibly, the illitisation of a smectite precursor.

Short-lasting, intensive growth of illite is recorded only at places. It seems that illitisation was more often a multi-stage process. If the long-lasting growth were the case, then a single result from one size fraction could be an average of unknown end-member ages and, thus, meaningless.

The K-Ar ages of authigenic illite generally coincide with the modelled time of gas generation from Carboniferous rocks and the filling of reservoirs in the area of the Fore-Sudetic Monocline. Possibly, the same underlying processes triggered illitisation and hydrocarbon migrations, or hydrocarbon migrations triggered fluid flows and illite crystallisation.

Although the Jurassic crystallisation of illite certainly occurred, the beginning of the process and its termination are unknown. All examinations conducted so far, including the present study, show some shortcomings which make the results fragmental and even disputable. There are some premises that the process had been long, began in the Triassic and prolonged until the Late (?) Cretaceous, but compelling evidence is still lacking.

Acknowledgements. The samples used in this study come from the Polish Oil and Gas Company (PGNiG). I thank G. Leśniak, Oil and Gas Institute in Cracow, for providing some samples. Sample Rokietnica-3 3665.8 belongs to the collection of W. Grocholski and H. Grocholska stored at the University of Poznań. I am grateful to M. Banaś, Polish Academy of Sciences, for performing the analytical work. D. Michalska generously helped with the SEM observations. Comments and suggestions by R. Gaupp, H. Kiersnowski, M. Kuberska, and T. Peryt - the Editor - are gratefully acknowledged. K. Leszczyński read and corrected the final version of the manuscript. The National Science Centre in Poland provided financial support (Grant No. NN 307 301236).

\section{REFERENCES}

Bechtel, A., Elliott, W.C., Wampler, J.M., Oszczepalski, S., 1999 Clay mineralogy, crystallinity, and K-Ar ages of illites within the Polish Zechstein Basin: implications for the age of the Kupferschiefer mineralization. Economic Geology, 94: 261-272.

Biernacka, J., 2014. Pore-lining sudoite in Rotliegend sandstones from the eastern part of the Southern Permian Basin. Clay Minerals, 49: 635-655.

Biernacka, J., Leśniak, G., Buniak, A., 2006. The influence of compaction and cementation on reservoir properties of Rotliegend sandstones from the Fore-Sudetic Monocline (in
Polish with English summary). Prace Instytutu Nafty i Gazu, 134: $1-67$.

Bonhomme, M.G., Bühmann, D., Besnus, Y., 1983. Reliability of $\mathrm{K}-\mathrm{Ar}$ dating of clays and silicifications associated with vein mineralizations in Western Europe. Geologische Rundschau, 72: $105-117$.

Botor, D., 2011. One-dimensional modelling of gas generation processes in Carboniferous sediments from the deep part of Polish Rotliegend basin (in Polish with English summary). Geologia, 37: 503-516. 
Botor, D., Papiernik, B., Maćkowski, T., Reicher, B., Kosakowski, P., Machowski, G., Górecki, W., 2013. Gas generation in Carboniferous source rocks of the Variscan foreland basin: implications for a charge history of Rotliegend deposits with natural gases. Annales Societatis Geologorum Poloniae, 83: 353-383.

Bylina, P., 2006. Low-grade metamorphism of Permian mafic rocks from the Gorzów Wielkopolski Block (Fore-Sudetic Monocline, SW Poland): age and mechanism. Mineralogia Polonica, 37: 3-50.

Cathelineau, M., Boiron, M.-C., Fourcade, S., Ruffet, G., Clauer, N., Belcourt, O., Coulibaly, Y., Banks, D.A., Guillocheau, F., 2012. A major Late Jurassic fluid event at the basin/basement unconformity in western France: ${ }^{40} \mathrm{Ar} /{ }^{39} \mathrm{Ar}$ and $\mathrm{K}-\mathrm{Ar}$ dating, fluid chemistry, and related geodynamic context. Chemical Geology, 322-323: 99-120.

Clauer, N., 2013. The $\mathrm{K}-\mathrm{Ar}$ and ${ }^{40} \mathrm{Ar} /{ }^{39} \mathrm{Ar}$ methods revisited for dating fine-grained K-bearing clay minerals. Chemical Geology, 354: 163-185.

Clauer, N., Chaudhuri, S., 1995. Clays in Crustal Environment. Isotope Dating and Tracing. Springer-Verlag, Heidelberg.

Clauer, N., Zwingmann, H., Chaudhuri, S., 1996. Isotopic (K-Ar and oxygen) constraints on the extent and importance of the Liassic hydrothermal activity in western Europe. Clay Minerals, 31: 301-318.

Clauer, N., Środoń, J., Francu, J., Šucha, V., 1997. K-Ar dating of illite fundamental particles separated from illite-smectite. Clay Minerals, 32: 181-196

Clauer, N., Liewig, N., Zwingmann, H., 2012. Time-constrained illitization in gas-bearing Rotliegende (Permian) sandstones from northern Germany by illite potassium-argon dating. AAPG Bulletin, 96: 519-543.

Eberl, D.D., Velde, B., 1989. Beyond the Kubler index. Clay Minerals, 24: 571-577.

Fischer, C., Dunkl, I., Eynatten, H., von, Wijbrans, J.R., Gaupp, R., 2012. Products and timing of diagenetic processes in Upper Rotliegend sandstones from Bebertal (North German Basin, Parchim Formation, Flechtingen High, Germany). Geologica Magazine, 149: 827-840.

Gast, R., Dusar, M., Breitkreuz, C., Gaupp, R., Schneider, J.W., Stemmerik, L., Geluk, M., Geißler, M., Kiersnowski, H., Glennie, K., Kabel, S., Jones N., 2010. Rotliegend. In: Petroleum Geological Atlas of the Southern Permian Basin Area (eds. J.C. Doornenbal and A.G. Stevenson): 101-121. EAGE Publications b.v. (Houten).

Gaupp, R., Matter, A., Platt, J., Ramseyer, K., Walzebuck, J. 1993. Diagenesis and fluid evolution of deeply buried Permian (Rotliegende) gas reservoirs, Northwest Germany. AAPG Bulletin, 77: 1111-1128.

Glennie, K., 1990. Early Permian - Rotliegend. In: Introduction to the Petroleum Geology of the North Sea (ed. K. Glennie): 120-152. Blackwell Scientific, Oxford.

Gradstein, F.M., Ogg, J.G., Smith, A.G., eds., 2004. A Geologic Time Scale 2004. Cambridge University Press, Cambridge.

Hamilton, P.J., Kelley, S., Fallick, A.E., 1989. K-Ar dating of illite in hydrocarbon reservoirs. Clay Minerals, 24: 215-231.

Haszeldine, R.S., Cavanagh, A.J., England, G.L., 2003. Effects of oil charge on illite dates and stopping quartz cement: calibration of basin models. Journal of Geochemical Exploration, 78-79: 373-376.

Karnkowski, P.H., 1999. Origin and evolution of the Polish Rotliegend Basin. Polish Geological Institute Special Papers, 3: 1-93.

Kiersnowski, H., 1997. Depositional development of the Polish Upper Rotliegend Basin and evolution of its sediments source areas. Geological Quarterly, 41 (4): 433-456.

Kiersnowski, H., 2013. Late Permian aeolian sand seas from the Polish Upper Rotliegend Basin in the context of palaeoclimatic periodicity. Geological Society Special Publications, 376 : 431-456.
Kiersnowski, H., Peryt, T.M., Buniak, A., Mikołajewski, Z., 2010a. From the intra-desert ridges to the marine carbonate island chain: middle to late Permian (Upper Rotliegend-Lower Zechstein) of the Wolsztyn-Pogorzela high, west Poland. Geological Journal, 44: 319-335.

Kiersnowski, H., Buniak, A., Kuberska, M., Srokowska-Okońka, A. 2010b. Tight gas accumulations in Rotliegend sandstones of Poland (in Polish with English summary). Przegląd Geologiczny, 58: 335-346.

Kotarba, M.J., Peryt, T.M., Kosakowski, P., Więcław, D., 2006. Organic geochemistry, depositional history and hydrocarbon generation modelling of the Upper Permian Kupferschiefer and Zechstein Limestone strata in south-west Poland. Marine and Petroleum Geology, 23: 371-386.

Kozłowska, A., Poprawa, P., 2004. Diagenesis of the Carboniferous clastic sediments of the Mazowsze region and the northern Lublin region related to their burial and thermal history (in Polish with English summary). Przegląd Geologiczny, 52: 491-500.

Lander, R.H., Bonnell, L.M., 2010. A model for fibrous illite nucleation and growth in sandstones. AAPG Bulletin, 94: 1161-1187.

Lee, M., Aronson, J.L., Savin, S.M., 1985. K/Ar dating of time of gas emplacement in Rotliegendes sandstone. AAPG Bulletin, 69: 1381-1385.

Lee, M., Aronson, J.L., Savin, S.M., 1989. Timing and conditions of Permian Rotliegende sandstone diagenesis, southern North Sea: K/Ar and oxygen isotopic data. AAPG Bulletin, 73: 195-215.

Liewig, N., Clauer, N., 2000. K-Ar dating of varied microtextural illite in Permian gas reservoirs, northern Germany. Clay Minerals, 35: $271-281$.

Maliszewska, A., Kuberska, M., 2009. Isotopic investigations of diagenetic illite of Rotliegend sandstones from the Wielkopolska and Western Pomerania regions (in Polish with English summary). Przegląd Geologiczny, 57: 322-327.

Menning, M., Alekseev, A.S., Chuvashov, B.I., Davydov, V.I., Devuyst, F.-X., Forke, H.C., Grunt, T.A., Hance, L., Heckel, P.H., Izokh, N.G., Jin, Y.-G., Jones, P.J., Kotlyar, G.V., Kozur, H.W., Nemyrovska, T.I., Schneider, J., Wang, X.-D., Weddige, K., Weyer, D., Work, D.M., 2006. Global time scale and regional stratigraphic reference scales of Central and West Europe, Tethys, South China, and North America as used in the Devonian-Carboniferous-Permian Correlation Chart 2003 (DCP 2003). Palaeogeography, Palaeoclimatology, Palaeoecology, 240: 318-372.

Meunier, A., Velde, B., Zalba, P., 2004. Illite K-Ar Dating and crysta growth processes in diagenetic environments: a critical review. Terra Nova, 16: 296-304

Meyer, M., Brockamp, O., Clauer, N., Renk, A., Zuther, M., 2000. Further evidence for a Jurassic mineralizing event in central Europe: K-Ar dating of hydrothermal alteration and fluid inclusion systematics in wall rocks of the Käfersteige fluorite vein deposit in the northern Black Forest, Germany. Mineralium Deposita, 35: 754-761.

Michalik, M., 2001. Diagenesis of the Weissliegend sandstones in the south-western margin of the Polish Rotliegend Basin. Prace Mineralogiczne, 91: 1-171.

Mossmann, J.R., Clauer, N., Liewig, N., 1992. Dating thermal anomalies in sedimentary basins: The diagenetic history of clay minerals in the Triassic sandstones of the Paris basin, France. Clay Minerals, 27: 211-226.

Nadeau, P.H., 1998. An experimental study of the effects of diagenetic clay minerals on reservoir sands. Clays and Clay Minerals, 46: 18-26.

Odin, G.S. (and 35 collaborators), 1982. Interlaboratory standards for dating purposes. In: Numerical Dating in Stratigraphy. Part 1 (ed. G.S. Odin): 123-148. John Wiley and Sons, Chichester, England.

Peaver, D.R., 1999. Illite and hydrocarbon exploration. Proceedings of the National Academy of Science, USA, 96: 3440-3446.

Peryt, T.M., Durakiewicz, T., Kotarba, M.J., Oszczepalski, S., Peryt, D., 2012. Carbon isotope stratigraphy of the basal 
Zechstein (Lopingian) strata in Northern Poland. Geological Quarterly, 56 (2): 285-298.

Platt, J.D., 1993. Controls on clay mineral distribution and chemistry in the Early Permian Rotliegend of Germany. Clay Minerals, 28: 393-416.

Pletsch, T., Appel, J., Botor, D., Clayton, C., Duin, E., Faber, E., Górecki, W., Kombrink, H., Kosakowski, P., 2010. Petroleum generation and migration. In: Petroleum Geological Atlas of the Southern Permian Basin Area (eds. J.C. Doornenbal and A.G. Stevenson): 225-253. EAGE Publications b.v., Houten.

Pollastro, R.M., 1993. Considerations and applications of the illite/smectite geothermometer in hydrocarbon-bearing rocks of Miocene to Mississippian age. Clays and Clay Minerals, 41: 119-133.

Protas, A., Hałas, S., Wójtowicz, A., 2006. K-Ar dating of illite from Rotliegend rocks of the Polish Lowland area (in Polish). In: Abstract book of the 9th Polish Scientific Session "Datowanie Minerałów i Skał", Gdańsk, 54-56.

Robinson, A.G., Coleman, M.L., Gluyas, J.G., 1993. The age of illite cement growth, Village Fields area, Southern North Sea: Evidence from $\mathrm{K}-\mathrm{Ar}$ ages and ${ }^{18} \mathrm{O} /{ }^{16} \mathrm{O}$ ratios. AAPG Bulletin, 77: 68-80.

Schwarzer, D., Littke, R., 2007. Petroleum generation and migration in the 'Tight Gas' area of the German Rotliegend natural gas play: a basin modeling study. Petroleum Geoscience, 13: 37-62.

Symons, D.T.A., Kawasaki, K., Walther, S., Borg, G., 2011 Paleomagnetism of the Cu-Zn-Pb-bearing Kupferschiefer black shale (Upper Permian) at Sangerhausen, Germany. Mineralium Deposita, 46: 137-152.

Środoń, J., 1984. X-ray powder diffraction identification of illitic materials. Clays and Clay Minerals, 32: 337-349.

Środoń, J., 2007. Illitization of smectite and history of sedimentary basins. Proceedings of the 11th EUROCLAY Conference, Aveiro, Portugal, 74-82.
Środoń, J., Eberl, D.D., Drits, V.A., 2000. Evolution of fundamental-particle size during illitization of smectite and implications for reaction mechanism. Clays and Clay Minerals, 48: 446-458.

Środoń, J., Clauer, N., Eberl, D.D., 2002. Interpretation of K-Ar dates of illitic clays from sedimentary rocks aided by modeling. American Mineralogist, 87: 1528-1535.

Środoń, J., Clauer, N., Banaś, M., Wójtowicz, A., 2006. K-Ar evidence for a Mesozoic thermal event superimposed on burial diagenesis of the Upper Silesia Coal Basin. Clay Minerals, 41: 669-690.

Wilkinson, M., Haszeldine, R.S., 2002. Fibrous illite in oilfield sandstones - A nucleation kinetic theory of growth. Terra Nova, 14: $56-60$.

Wilson, M.J., Wilson, L., Patey, I., 2014. The influence of individual clay minerals on formation damage of reservoir sandstones: a critical review with some new insights. Clay Minerals, 49: 147-164.

Ziegler, K., 2006. Clay minerals of the Permian Rotliegend Group in the North Sea and adjacent areas. Clay Minerals, 41: 355-393.

Ziegler, K., Sellwood, B.W., Fallick, A.E., 1994. Radiogenic and stable isotope evidence for age and origin of authigenic illites in the Rotliegend, southern North Sea. Clay Minerals, 29: 555-565.

Zwingmann, H., Clauer, N., Gaupp, R., 1998. Timing of fluid-flow in a sandstone reservoir of the north German Rotliegend (Permian) by K-Ar dating of related hydrothermal illite. Geological Society Special Publications, 144: 91-106.

Zwingmann, H., Clauer, N., Gaupp, R., 1999. Structure-related geochemical (REE) and isotopic (K-Ar, Rb-Sr, $\left.{ }^{18} \mathrm{O}\right)$ characteristics of clay minerals from Rotliegend sandstone reservoirs (Permian, northern Germany). Geochimica et Cosmochimica Acta, 63: 2805-2823. 